Egyptian Journal of Aquatic Biology \& Fisheries

Zoology Department, Faculty of Science,

Ain Shams University, Cairo, Egypt.

ISSN 1110 - 6131 Vol. 21(3): 11-28 (2017)

www.ejabf.journals.ekb.eg

\title{
Antioxidant Defense System Alternations in Fish as a Bio-Indicator of Environmental Pollution
}

\author{
Magdy, T. Khali1 ${ }^{1}$; Nahed, S. Gad ${ }^{2}$; Nasr, A.M. Ahmed ${ }^{2}$ and Sally S. Moustafa*2 \\ ${ }^{1}$ Department of Zoology, Faculty of Science, Ain Shams University, Cairo, Egypt \\ ${ }^{2}$ National Institute of Oceanography and Fisheries (NIOF), Cairo, Egypt
}

\begin{abstract}
*Correspondence to Sally S. Moustafa, National Institute of Oceanography and Fisheries (NIOF), Cairo, Egypt.E-mail: sallyissun@yahoo.com
\end{abstract}

\section{ARTICLE INFO \\ Article History: \\ Received: July, 2017 \\ Accepted: July, 2017 \\ Available online: July, 2017}

\section{Keywords:}

Antioxidant defence system

Fish

Heavy metals

River Nile

Rosetta Branch

\section{ABSTRACT}

The present study carried out to clarify the impact of heavy metals $(\mathrm{Fe}, \mathrm{Zn}, \mathrm{Cu}, \mathrm{Mn}$ and $\mathrm{Cd}$ ) pollution of Rosetta Branch on the antioxidant defence system activities and lipid peroxidation indicator MDA levels in $O$. niloticus tissues (liver and white muscles) collected from three stations from Rosetta Branch of River Nile in summer 2014 and winter 2015. Rosetta Branch of River Nile exposed to high input of agricultural drainage water, sewage and industrial waste water which influence the living organisms especially fish. In the present study, results revealed that high concentrations of heavy metals $(\mathrm{Fe}, \mathrm{Zn}, \mathrm{Cu}, \mathrm{Mn}$ and $\mathrm{Cd})$ were detected in water and fish samples, especially in winter. In muscles of O. niloticus, the accumulation patterns of heavy metals were in the following order: $\mathrm{Fe}>\mathrm{Zn}>\mathrm{Mn}>\mathrm{Cu}$ and $\mathrm{Cd}$. The bioaccumulation factor (BAF) in winter was higher than summer. Antioxidant enzymes (SOD, CAT, GPx, GST and GR) activities and the indicator of lipid peroxidation MDA levels in liver and white muscles of $O$. niloticus were found to be significantly increased compared to the reference values, especially in winter. Moreover, the antioxidant enzymes activities and MDA levels were higher in liver than white muscles. These remarkable alterations in the activity of the selected enzymes in the liver and white muscles of the $O$. niloticus go in parallel with the elevation in the levels of heavy metals detected in the water of Rosetta branch, as a result of pollution stress in these areas. Thus we conclude that, the altered activities of SOD, CAT, GPx, GST and GR) and MDA levels could be useful biomarkers of water pollution.

\section{INTRODUCTION}

River Nile is the longest river in the world. It is the main source of water in Egypt that has a wide usage in different fields, drinking and domestic water supply agricultural, industrial investigation, fishery and others (El-Sayed and Ouf, 2009). 
Pollution load in the Nile system (River Nile, canals, and drains) has increased in the past few decades due to population increases, several new irrigated agriculture projects, new industrial projects and other activities along the River Nile. Consequently, quality of Nile water worsened dramatically in the past few years (Abdel-Dayem et al., 2007). The most polluted part of River Nile is the two branches, Damietta and Rosetta (NAWQAM, 2003). Heavy metals pollution in fish has become a worldwide concern, not only because of the threat to fish, but also the health risks associated with consumption (Lee et al., 2011).

Heavy metals are considered as serious pollutants of aquatic ecosystem because of their environmental persistence and toxicity effects on living organisms. Heavy metals enter the surroundings by natural means and through human activities (Barbosa-Morais et al., 2012). Freshwater fish, occupying upper levels of trophic chains, it can accumulate non-degradable pollutants, like metals, in different tissues, including liver and white muscle (Adeyeye et al., 1996). The induced metabolic alternations in these tissues can serve as indicators of freshwater ecosystem contamination by heavy metals and constitute health hazard of fish and human health (Ahmed et al., 2015).

Heavy metals can be taken up into fish either from digestion or contaminated food via alimentary track or through gills or skin after the absorption it transported through blood stream to the organs and tissues, where they are accumulated. Fish can regulate metal concentrations to a certain extent, after the occurrence of bioaccumulation.

Previous studies have reported that exposure of fish to pollutants (agricultural, industrial and sewage) affects the antioxidative defense system enzymes such as: SOD, CAT, GST, and GR (Hegazi et al., 2010). It is suggested that some of these enzymes can constitute good molecular bioindicators for oxidative stress and can indicate the magnitude of response in vertebrate population chronically exposed to contaminants, such as metals and other xenobiotic (Gad, 2009).

Several circumstances promote the antioxidant defence response in fish, factors intrinsic to the fish itself such as: age, reproductive, metabolic status of fish and environmental conditions, that include food availability, oxygen level, temperature of water, salinity and photoperiod, toxins present in the water or pathologies, can either fortify or weaken antioxidant defences (Melegaria et al. 2013). The accumulation of heavy metals can produce increasing amount of (ROS) in fish by generating free radicals such as the hydroxyl radical $\left(\mathrm{OH}^{*}\right)$, proxy radical $\left(\mathrm{RO}_{2}{ }^{\circ}\right)$ and superoxide $\left(\mathrm{O}_{2} \bullet\right)$ and some non-radical such as hydrogen peroxide $\left(\mathrm{H}_{2} \mathrm{O}_{2}\right)$, this led to the induction of enzymatic antioxidants (SOD, CAT, GST, GR and GPx) and non-enzymatic antioxidant glutathione (GSH). These antioxidants scavenge free radicals and provide protection against this aspect of oxygen toxicity (Kadar $\boldsymbol{e t}$ al., 2005). Oxidative stress occurs when the equilibrium between ROS production and the antioxidant defenses is lost, ROS can be important mediators of damage to cell structures, including lipids and membranes, proteins and nucleic acids, that can seriously alter the cell membranes and other structures such as proteins, lipids, lipoproteins, and deoxyribonucleic acid (DNA) which lead to different pathologic processes, and fish diseases (Pereira et al., 2011).

The first line of defense against oxidative stress is SOD and CAT. SOD catalyzes the superoxide anion radical $\left(\mathrm{O}_{2}{ }^{-}\right)$dismutation into hydrogen peroxide $\left(\mathrm{H}_{2} \mathrm{O}_{2}\right)$ by reduction. The oxidant formed $\left(\mathrm{H}_{2} \mathrm{O}_{2}\right)$ is transformed into water and oxygen $\left(\mathrm{O}_{2}\right)$ by catalase (CAT) or glutathione peroxidase (GPx) (Stara et al. 2012). GPx enzyme removes $\mathrm{H}_{2} \mathrm{O}_{2}$ by using it to oxidize reduced glutathione (GSH) into oxidized glutathione (GSSG). Glutathione reductase GR is a flavoprotein enzyme, 
regenerates GSH from GSSG, using NADPH as a source of reducing power. Besides hydrogen peroxide, GPx also reduces lipid or non-lipid hydroperoxides while oxidizing glutathione (GSH) (Genestra, 2007).

On the other hand, there is a few biochemical studies on the antioxidant defence system carried out on the fish collected from Rosetta Branch of River Nile. Therefore, this study was conducted to determine the level of some heavy metals in water and muscles of $O$. niloticus and evaluate the impact of such pollutants on antioxidant defence enzymes in liver and white muscles of fish. Moreover, the study trends to provide new data for further research in metal carcinogenicity that would help predicting the toxicological hazards to aquatic life and human.

\section{MATRIALS AND METHODS}

\section{Area of Investigation}

Rosetta Branch of River Nile is about $220 \mathrm{Km}$ length and about $180 \mathrm{~m}$ width with an average depth of 2.0 to $2.3 \mathrm{~m}$. It starts from EL-Qanater EL-Khayria and ends at Rosetta Estuary. It passed cutting six governorates; EL-Qalubia, EL-Menofiya, ELGiza, EL-Gharbiya, Kafr El-Shiekh and EL-Boheira Governorates. Rosetta Branch selected to be the area of investigation, from El-Qanater El-Khayria to Kafr El-Zayat city; distance about $95.25 \mathrm{Km}$ (Fig. 1).

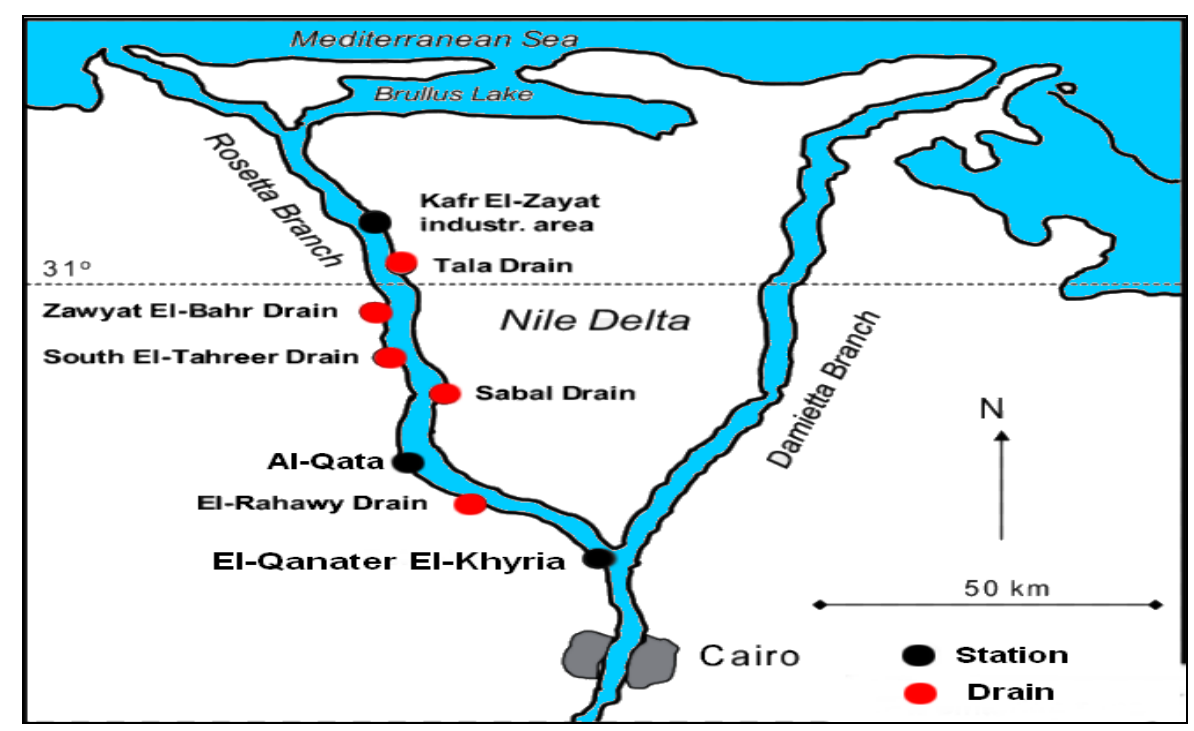

Fig. (1): A map of northern Egypt showing area of study and sampling stations of the Rosetta Branch.

There are three main sources of pollution discharged into Rosetta Branch which, potentially affects and deteriorates the water quality of it; (1) El-Rahawy drain, which discharged more than 1,9 million $\mathrm{m}^{3} /$ day of agricultural, domestic and sanitary wastes into Rosetta Branch. (2) Kafr El-Zayat industrial area, which includes the industrial effluents from the factories of super phosphate and sulfur compounds, oil and soap industries and pesticides factories. (3) Various small agricultural drains and sewage from several cities and its neighboring villages, which discharge their wastes directly into the branch without treatment.

\section{Collection of Samples:}

Water and fish samples were collected from three stations from Rosetta Branch of River Nile: (1) El-Qanater El-Khyria. (2) Al Qata. (3) Kafr El-Zayat, in spring 2014 and winter 2015. Water samples were collected in polyethylene bottles at two meter depth from selected stations, then acidified using nitric acid and transferred in ice box to laboratory to be analyzed. 
Fish (O. niloticus) samples of were collected with the help of fishermen, the collected fish with an average body weight $(150 \pm 10 \mathrm{gm})$, and an average body length $(19 \pm 5 \mathrm{~cm})$. After dissection of fish, muscle tissues were separated for determination of heavy metal accumulation. Moreover, the right lobe of liver and white muscles tissues were carefully removed for evaluation of antioxidant enzymes activity and MDA levels.

Determination of Heavy metals in water and fish muscles:

Water samples of $500 \mathrm{ml}$ were acidified with conc. nitric and heated on a hot plat. Heating and addition of conc. Nitric acid were continued till complete digestion of heavy metals ( $\mathrm{Fe}, \mathrm{Zn}, \mathrm{Cu}, \mathrm{Mn}$, and $\mathrm{Cd}$ ) as described by (APHA, 2012). Fish samples were digested after drying according to the method described by Ghazaly (1988). The levels of heavy metals determined using GBC atomic absorption reader (Model SavantAA AAS with GF 5000 Graphite Furnace), results in water were expressed in (mg/L) and in $\mathrm{mg} / \mathrm{kg}$ dry wt. in fish muscles.

\section{Bioaccumulation Factor for Heavy Metals in Fish Muscle (BAF)}

According to EPA guidelines, the BAF is defined as the ratio of chemical concentration in the organism to that in the surrounding water.

$$
\mathbf{B A F}=\mathbf{M}_{\text {(tissue) }} / \mathbf{M}_{\text {(water) }} \text {. }
$$

Where; $\mathrm{M}$ tissue is the metal concentration in fish tissue $\mathrm{mg} / \mathrm{kg}$ and $\mathrm{M}$ water, metal concentration in water $\mathrm{mg} / \mathrm{L}$.

\section{Biochemical analysis}

Fish were carefully dissected on ice, excised pieces of white muscles or right lobe of liver tissue of $O$. niloticus fish were washed with isotonic saline, dried using filter paper and weighted $(n=8)$, tissues were quickly homogenized in ice-cold 50 $\mathrm{mM}$ phosphate buffer, $1 \%$ Triton $\mathrm{X} 100(\mathrm{pH} 7.4)$ to give a $10 \%$ homogenate. then centrifuged at $6,000 \mathrm{xg}$ in cooling centrifuge at $4{ }^{\circ} \mathrm{C}$ for $15 \mathrm{~min}$, the supernatant was saved for immediate assay of enzymes activity in liver and white muscles.

The activity of total superoxide dismutase (SOD) was determined in fish tissues using the NADH oxidation method of Paoletti and Mocali (1990). The unit of activity is defined as the amount of enzyme causing 50\% inhibition of the rate of the superoxide driven NADH oxidation, the absorbance was monitored at $340 \mathrm{~nm}$, enzyme activity was calculated using a calibration curve made from standard SOD. The specific activity was expresses as unit per gram wet weight tissue (U/mg).

Catalase activity was assayed according to the method of Xu et al. (1997) using $\mathrm{H}_{2} \mathrm{O}_{2}$ substrate solution (freshly prepared), absorbance readings at $240 \mathrm{~nm}$, it was defined as the amount of extract needed to decompose of $\mathrm{H}_{2} \mathrm{O}_{2}$ per min. activity was expressed as $\mu \mathrm{mol} / \mathrm{min} / \mathrm{g} \mathrm{w}$.wt.

Glutathione peroxidase (GPx) activity was assayed according to the method of Paglia and Valentine (1967), using glutathione reductase (GR) and NADPH, the reaction started by the addition of $\mathrm{H}_{2} \mathrm{O}_{2}$. Oxidation of $\mathrm{NADPH}$ to $\mathrm{NADP}^{+}$was monitored continuously at $25^{\circ} \mathrm{C}$, reading absorbance at $340 \mathrm{~nm}$. every 15 seconds for 300 seconds. Data were expressed as ( $\mu \mathrm{M} / \mathrm{min} / \mathrm{g}$ w.wt.).

Glutathione-S-transferase (GST) activity assayed according to the method of Habig et al. (1974), it based on the formation of CDNB (S-2,4-dinitrophenyl glutathione) adduct, it was monitored by the increase in absorbance at $340 \mathrm{~nm}$. GST activity was expressed as $\mu \mathrm{M} / \mathrm{min} / \mathrm{g}$ w.wt.

The determination of Glutathione Reductase (GR) activity was measured by the method of Smith et al. (1988), The reduction of 5,5'-dithiobis-2-nitrobenzoic acid (DTNB) to TNB was measured, the reaction initiated by the addition of oxidized 
glutathione (GSSG) at $25^{\circ} \mathrm{C}$. The absorbance was recorded at $340 \mathrm{~nm}$ over a period of $5 \mathrm{~min}$., GR activity was expressed as $\mu \mathrm{M} / \mathrm{min} / \mathrm{g}$ w.wt.

Lipid peroxidation is the degradation of Lipids by reactive oxygen species, resulting in a chain reaction with the production of end products, such as malondialdehyde (MDA), which is a useful marker for oxidative stress. The concentration of MDA was evaluated by the method of Buege and Aust (1978). MDA reacts with TBA (thiobarbituric acid) to form a conjugate, absorbance was read at $532 \mathrm{~nm}$ against the reagent blank, and expressed as nmol/mg protein.

\section{Statistical Analysis}

The experimental data were subjected to statistical analysis by one-way analysis of variance (ANOVA), the significant of difference was analyzed by the Dunnett test (compare data of all vs. control), using a software program (GraphPad InStat Software, Inc.). The difference checked by one-way (ANOVA) was significance when $(\mathrm{P} \leq 0.05)$, each reading represents (Mean \pm S.E) of 8 fish.

\section{RESULTS}

\section{Concentration of heavy metals in water:}

The mean concentrations of the selected heavy metals in water of Rosetta Branch of the River Nile are presented in table (1). The concentration of $\mathrm{Fe}, \mathrm{Zn}, \mathrm{Cu}$, $\mathrm{Mn}$ and $\mathrm{Cd}$ in water of the selected stations ranged between (0.173-0.775), (0.093$0.124),(0.008-0.113),(0.016-0.078)$ and $(0.011-0.023) \mathrm{mg} / \mathrm{L}$ in summer, and ranged between (0.223-0.952), (0.111-0.193), (0.022-0.177), (0.049-0.171) and (0.016-0.034) $\mathrm{mg} / \mathrm{L}$ in winter respectively. The station (3) Kafr El-Zayat had the highest levels of heavy metals while, station (1) El-Qanater El-Khayria had the lowest values during period of sampling. The results showed that, Fe recorded the highest concentration $(0.173-0.952 \mathrm{mg} / \mathrm{l})$ among the tested metals, while $\mathrm{Cd}$ recorded the lowest one (0.011$0.034 \mathrm{mg} / \mathrm{l})$ during the study period. Also, the concentrations of $\mathrm{Fe}, \mathrm{Zn}, \mathrm{Cu}, \mathrm{Mn}$ and $\mathrm{Cd}$ in water were elevated in winter compared to summer at the three stations.

Table (1): Heavy metals concentrations (mg/L) in water from Rosetta Branch of River Nile during summer 2014 and winter 2015.

\begin{tabular}{ccccccc}
\hline $\begin{array}{c}\text { Heavy } \\
\text { metal }\end{array}$ & Season & Station I & Station II & Station III & (Mean \pm S.E) & $\begin{array}{c}\text { Law48/1982 } \\
\text { Decree92/2013 }\end{array}$ \\
\hline Fe & $\mathbf{S}$ & 0.173 & 0.603 & 0.775 & $0.517 \pm 0.18$ & 0.5 \\
& $\mathbf{W}$ & 0.223 & 0.772 & 0.952 & $0.65 \pm 0.22$ & \\
\hline $\mathbf{Z n}$ & $\mathbf{S}$ & 0.093 & 0.119 & 0.124 & $0.112 \pm 0.01$ & 0.01 \\
& $\mathbf{W}$ & 0.111 & 0.147 & 0.193 & $0.15 \pm 0.02$ & \\
\hline $\mathbf{C u}$ & $\mathbf{S}$ & 0.008 & 0.011 & 0.133 & $0.05 \pm 0.03$ & 0.01 \\
& $\mathbf{W}$ & 0.022 & 0.143 & 0.177 & $0.11 \pm 0.04$ & 0.2 \\
\hline $\mathbf{M n}$ & $\mathbf{S}$ & 0.016 & 0.062 & 0.078 & $0.052 \pm 0.02$ & 0.001 \\
& $\mathbf{W}$ & 0.049 & 0.144 & 0.171 & $0.121 \pm 0.04$ & \\
\hline $\mathbf{C d}$ & $\mathbf{S}$ & 0.011 & 0.019 & 0.023 & $0.017 \pm 0.003$ & 0.001 \\
& $\mathbf{W}$ & 0.016 & 0.024 & 0.034 & $0.025 \pm 0.004$ & W: winter
\end{tabular}

\section{Concentration of heavy metals and BAF in $O$. niloticus tissues:}

In the obtained results Table (2) showed the mean concentrations of heavy metals $\mathrm{Fe}, \mathrm{Zn}, \mathrm{Cu}, \mathrm{Mn}$ and $\mathrm{Cd}$ in muscles of $O$. niloticus during summer were (29.2 \pm 11.1$),(4.97 \pm 1.21),(1.1 \pm 0.51),(0.817 \pm 0.30)$ and $(0.106 \pm 0.06) \mathrm{mg} / \mathrm{kg}$ dry wt., respectively, while were $(60.5 \pm 25.9),(11.1 \pm 3.1),(6.4 \pm 1.7),(3.56 \pm 1.6)$ and $(0.252 \pm 0.08) \mathrm{mg} / \mathrm{kg}$ dry wt. during winter, respectively.

In muscles of $O$. niloticus the highest concentrations of $\mathrm{Fe}, \mathrm{Zn}, \mathrm{Cu}, \mathrm{Mn}$ and Cd were $103.75,16.13,7.65,5.94$ and $0.36 \mathrm{mg} / \mathrm{kg}$ dry wt. respectively, at station III 
in winter, while the lowest accumulation of $\mathrm{Fe}, \mathrm{Zn}, \mathrm{Cu} \mathrm{Mn}$ and $\mathrm{Cd}$ were 8.25, 2.97, $. \cdot 47,0.22$ and $0.032 \mathrm{mg} / \mathrm{kg}$ dry wt. at station I in summer, respectively. In the present study, station I recorded the lowest accumulation of the studied heavy metals in muscles of $O$. niloticus, while station III was the highest Table (2).

Table (2): Heavy metals concentrations (mg/ kg dry wt.) in O. niloticus muscles collected Rosetta Branch of River Nile in summer 2014 and winter 2015.

\begin{tabular}{ccccccc}
\hline Heavy metal & Season & Station I & Station II & Station III & (Mean \pm S.E) & FAO(1983) \\
\hline Fe & S & 8.25 & 34.35 & 45.16 & $29.2 \pm 11.1$ & 30 \\
& W & 15.55 & 62.3 & 103.75 & $60.5 \pm 25.9$ & \\
\hline $\mathbf{Z n}$ & $\mathbf{S}$ & 2.97 & 4.84 & 7.11 & $4.97 \pm 1.21$ & 30 \\
& $\mathbf{W}$ & 6.01 & 11.21 & 16.13 & $11.1 \pm 3.1$ & \\
\hline $\mathbf{C u}$ & $\mathbf{S}$ & 0.047 & 1.19 & 2.1 & $1.1 \pm 0.51$ & 30 \\
& $\mathbf{W}$ & 0.69 & 5.74 & 7.62 & $4.6 \pm 1.7$ & \\
\hline $\mathbf{M n}$ & $\mathbf{S}$ & 0.22 & 1.02 & 1.21 & $0.817 \pm 0.30$ & --- \\
& $\mathbf{W}$ & 0.62 & 4.11 & 5.94 & $3.56 \pm 1.6$ & \\
\hline $\mathbf{C d}$ & $\mathbf{S}$ & 0.032 & 0.095 & 0.19 & $0.106 \pm 0.05$ & 0.5 \\
& $\mathbf{W}$ & 0.114 & 0.283 & 0.36 & $0.32 \pm 0.03$ & \\
\hline (I) El-Qanater El-Khyria. & (II) Al Qata. & (III) Kafr El-Zayat. & S: summer. & W: winter.
\end{tabular}

The maximum BAF of metals $\mathrm{Fe}, \mathrm{Zn}, \mathrm{Cu}, \mathrm{Mn}$ and $\mathrm{Cd}$ in muscles of $O$. niloticus was $(108.9,83.4,43.1,34.5$ and 12.3) at station III in winter, whilst the lowest BAF was $(47.7,31.1,5.9,8.14$ and 3.3) at station I during summer, respectively. The results indicated that the BAF of heavy metals in muscles of $O$. niloticus were in the following order: $\mathrm{Fe}>\mathrm{Zn}>\mathrm{Cu}>\mathrm{Mn}$ and $\mathrm{Cd}$ (Table 3).

Table (3): The bioaccumulation factor (BAF) In O. niloticus muscles collected from Rosetta Branch of River Nile in summer 2014 and winter 2015.

\begin{tabular}{|c|c|c|c|c|}
\hline Heavy metal & Season & Station I & Station II & Station III \\
\hline \multirow[t]{2}{*}{$\mathbf{F e}$} & $\mathbf{S}$ & 47.7 & 56.9 & 58.2 \\
\hline & W & 69.7 & 80.7 & 108.9 \\
\hline \multirow[t]{2}{*}{$\mathbf{Z n}$} & $\mathbf{S}$ & 31.1 & 40.6 & 57.1 \\
\hline & W & 53.9 & 76.2 & 83.4 \\
\hline \multirow[t]{2}{*}{$\mathbf{C u}$} & $\mathbf{S}$ & 5.9 & 10.8 & 14.7 \\
\hline & W & 31.7 & 40.1 & 43.1 \\
\hline \multirow[t]{2}{*}{ Mn } & $\mathbf{S}$ & 8.14 & 15.4 & 15.6 \\
\hline & $\mathbf{W}$ & 12.6 & 28.4 & 34.5 \\
\hline \multirow[t]{2}{*}{ Cd } & $\mathbf{S}$ & 3.3 & 7.1 & 8.2 \\
\hline & W & 6.9 & 11.1 & 12.3 \\
\hline
\end{tabular}

(I) El-Qanater El-Khyria.

(II) Al Qata.

(III) Kafr El-Zayat.

S: summer

$\mathrm{W}$ : winter

\section{Biochemical parameters:}

The mean SOD activity in liver and white muscles of $O$. niloticus (Fig. 2) showed a highly significant increase $(\mathrm{P} \leq 0.01)$ at station III as compared with their respective control (site I).During the two sampling seasons, the increase in winter was 36.5 and $49.7 \%$ in white muscles and 41.1 and $62.9 \%$ in liver at each station, respectively. In summer the increase was 33.9 and $41.2 \%$ in white muscles; in liver was 35.3 and $54.4 \%$ at each sampling station, respectively. The CAT enzyme mean activity (Fig. 3) showed a highly significant increase $(\mathrm{P} \leq 0.01)$ in liver and white muscles in winter at stations II and III, The increase in winter was 39.6 and 59.1. \% in white muscles, in liver was 41.71 and $57.1 \%$ at each sampling station, respectively. In summer the CAT enzyme increase was 33.8 and $49.8 \%$ in white muscles and 35.5 and $50.9 \%$ in liver at each sampling station, respectively. 


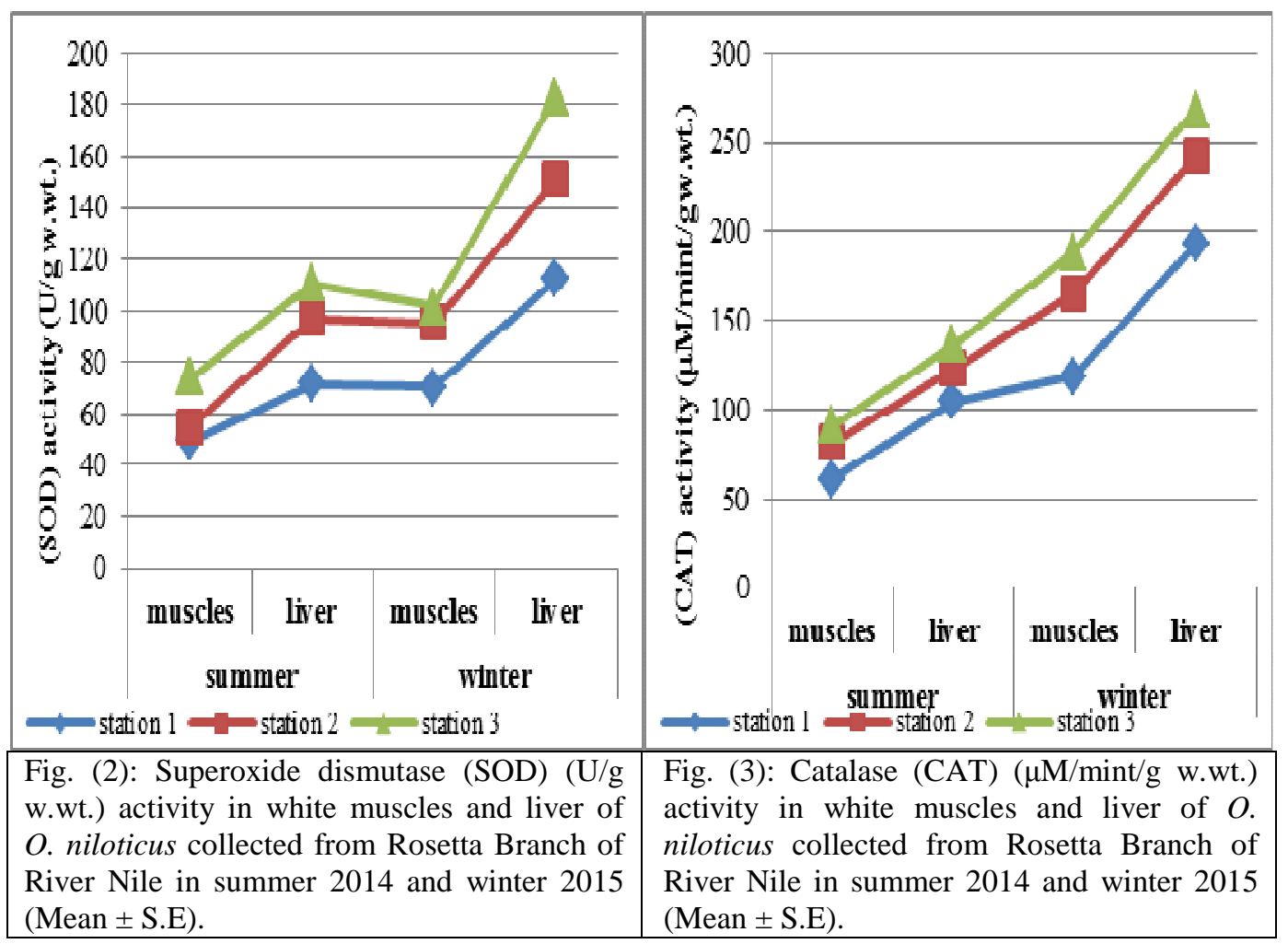

GPx activity of $O$. niloticus (Fig. 4) increased 1.4 and 1.6 fold in white muscles, and 1.6 and 1.8 fold in liver at stations II and III in winter, respectively. In summer the GPx enzyme increase was 1.3 and 1.6 fold in white muscles, and 1.8 and 2 fold in liver at each sampling station, respectively. GST activity (Fig. 5) in white muscles and liver of $O$. niloticus increased significantly at station III, liver highly significant increased $(\mathrm{P} \leq 0.01)$ in winter at station III compared to reference station I. GST activity in winter increase 1.8 and 2.1 fold in white muscles, and 1.9 and 2.4 fold in liver at stations II and III, respectively. In summer the GST enzyme increase was 1.2 and 1.7 fold in white muscles, and 1.5 and 2.1 fold in liver at each sampling station, respectively. GR mean activity (Fig. 6) showed a significant increase $(\mathrm{P} \leq 0.05)$ in white muscles and liver of $O$. niloticus at station III. GR activity increase in summer was 1.2 and 1.5 fold in white muscles and 1.4 and 2 fold in liver at each sampling station, respectively. In winter the GST enzyme activity increase was 1.4 and 1.6 fold in white muscles, and 1.7 and 1.9 fold in liver at each sampling station, respectively.

MDA levels (Fig. 7) were increased at station III in liver 2.1 and 2 fold, while increased 1.6 and 1.5 fold in white muscles in summer and winter respectively. MDA level increase in summer was 1.6 and 2 fold in white muscles and 1.7 and 2.1 fold in liver at each sampling station, respectively. In winter the MDA level increase was 1.5 and 1.8 fold in white muscles, and 1.7 and 2 fold in liver at each sampling station, respectively.

The studied enzymes (SOD, CAT, GPx, GST and GR) activity and MDA levels in liver and white muscles increased from lowest values in summer to the maximum in winter, while station III were the highest in enzymes activity and MDA levels, in compare with station I and II. 

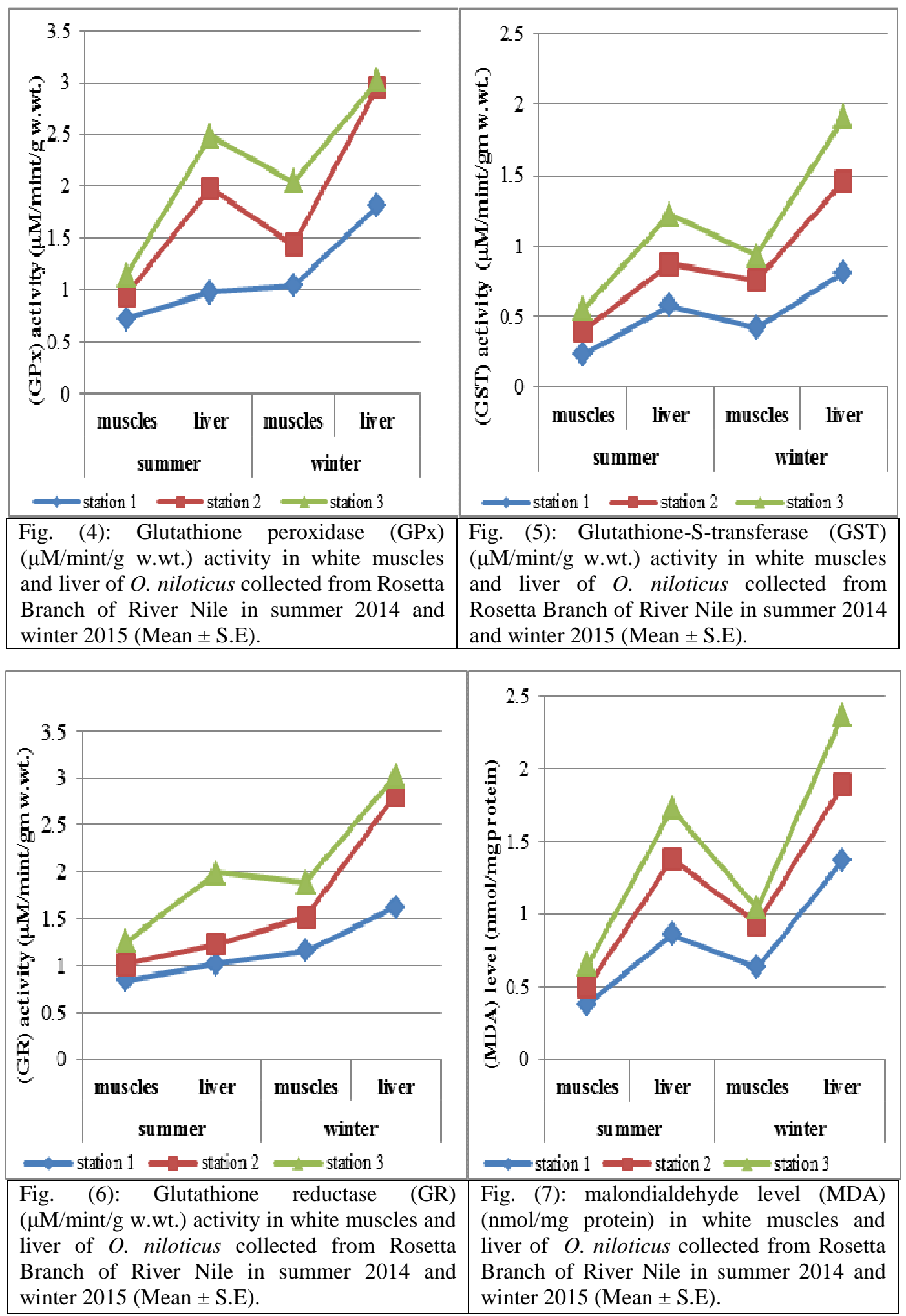

\section{DISCUSSION}

In the present study the increase of Fe in water is mainly due to liberation of Fe as ferrous ions from sediments and industrial wastes effluent from Kafr El-Zayat industrial area. However, the minimum values of $\mathrm{Fe}$ may be due to oxidation of $\left(\mathrm{Fe}^{+2}\right)$ to $\left(\mathrm{Fe}^{+3}\right)$, which precipitate as $\mathrm{Fe}\left(\mathrm{OH}_{3}\right)$ to the sediment of the oxygenated water. 
Zinc $(\mathrm{Zn})$ concentration in water samples of the study area recorded the highest values in winter. This is mainly due to decrease in and $\mathrm{Zn}$ absorption with drop of water during winter and dissolution of clay containing zinc ions giving high content of zinc in water, or due to the decay of phytoplankton (El-Hadad, 2005).

The decrease in $\mathrm{Cu}$ concentration in water is mainly due to tendency to form complex with organic legends and humic matter, which leads to decreasing the penetration of free ions in water, where $90 \%$ of $\mathrm{Cu}$ in water were complexes by dissolved organic materials and suspended matters (Mantoura et al., 1978).

Manganese concentration in water samples collected from Rosetta Branch within the permissible levels Table (1). Cd concentration in water samples in present work exceeded the permissible limit.

Generally the concentrations of investigated heavy metals in water samples in present study were in the following order: $\mathrm{Fe}>\mathrm{Zn}>\mathrm{Mn}>\mathrm{Cu}$ and $\mathrm{Cd}$. Moreover, heavy metal concentrations in water samples showed seasonal variations. As elevated in cold season (winter), while decreased in hot season (summer). This in agreement with the results obtained by EI Bouraie $\boldsymbol{e t}$ al. (2010) and Islam et al. (2015b), whom reported that, heavy metals concentration showed seasonal variations and increased in winter.

The observed decline in heavy metals concentration in present work during hot seasons may be attributed to: (1) phytoplankton growth which can absorb large quantity of heavy metals from water. (2) heavy metals are more likely attached to organic matter and clays, which have surface functional groups (negatively charged) that bind heavy metal (positively charged) and settled down in sediments. (3) dilution effect of river water for high rainfall (Islam et al., 2015a). On the other side, the recorded elevation in heavy metals concentration in water samples in our study during cold seasons maybe due to: (1) winter closure period lead to water levels decrease, results in increase in concentration of the metals (Abdel-Moati and El-Sammak, 1997). (2) the fluctuation of the amount of agricultural drainage water, sewage effluents and industrial wastes discharged into water (Zyadah, 1995).

Heavy metals ( $\mathrm{Fe}, \mathrm{Zn}, \mathrm{Cu}, \mathrm{Mn}$ and $\mathrm{Cd}$ ) concentration in water samples collected from Rosetta Branch at stations (II and III) recorded higher level of heavy metals than station (I), this may due to the impact of pollution sources in these sites, as sewage, domestic wastes and other pollutants that discharged in El-Rahawy drain and the industrial effluents at Kafr El-Zayat industrial area, that poured directly into the branch water without treatment as reported by Authman et al. (2013).

\section{Heavy metal concentrations in fish muscles}

Contamination of aquatic environment with toxic element has seriously increased worldwide duo to the progressive industrialization. Studies carried out on fish have shown that, trace elements may have toxic effects, altering physiological activities and biochemical parameters both in blood and tissues (Gad and Ibrahim, 2005). Since the toxic effects of metals have been recognized, heavy metals affected directly or indirectly on aquatic organisms, this leads to hazardous effect on human health duo to, their biomagnifications over time (Malik et al., 2010).

Thus, determination of accumulated metals in fish is extremely important form the human health point of view. Fish species mostly absorbed heavy metals from its feeding diets, sediments and surrounding waters resulting to their accumulation in reasonable amounts (McCarthy and Shugart, 1996). Moreover, bioaccumulation of heavy metals in fish critically influences the growth rate, physiological and biochemical status and consequently the meat quality of fish (Elghobashy et al., 2001). The current study showed that, the highest concentrations of iron $(\mathrm{Fe})$ in muscles of O. niloticus Table (2), was recorded at station III (Kafr El-Zayat), and the 
lowest value at station I (relatively unpolluted site). The highest accumulation of ( $\mathrm{Fe})$ in fish muscles attributed to the large quantity of iron in water. The accumulated levels of $(\mathrm{Fe})$ in $O$. niloticus muscles were higher in winter than in summer. The increase of $(\mathrm{Fe})$ in water is mainly duo to liberation of $\mathrm{Fe}$ as ferrous ions from sediments and industrial wastes effluents from Kafr El-Zayat industrial area station III, however the minimum values in site (1) maybe duo to oxidation of $\mathrm{Fe}_{2}{ }^{+}$to $\mathrm{Fe}_{3}{ }^{+}$ which precipitates as $\mathrm{Fe}(\mathrm{OH})_{3}$ to the sediment of the oxygenated water. These results agree with the data obtained by Gad and Yacoub (2009) in the same sampling site, with Gad and Mohamed (2010) in O. niloticus and lates niloticus collected from Damietta branch of River Nile. The concentration of Iron in muscles of O. niloticus collected from Rosetta Branch of River Nile exceeded the permissible levels at stations II and III.

Zinc $(\mathrm{Zn})$ is an essential micro nutrient required for normal growth and metabolic function for various fish species, zinc is known to be toxic to fish, it causes mortality, growth retardation, tissues alternation, respiration and cardiac changes, inhibition of spawning, destroys the gill epithelium and consequently causes tissues hypoxia (Spear, 1981). In the present study the concentration of $\mathrm{Zn}$ in muscles of $O$. niloticus collected from Rosetta Branch of River Nile (Tables 3 and 4) showed an elevation in winter at station II and III in winter. These results in accordance with those obtained by Authman and Abbas (2007) and Gad and Yacoub (2009).

Cupper $(\mathrm{Cu})$ is essential for good health but, a very high intake can cause adverse health problems, such as liver and kidney damage (Ikem and Egiebor, 2005). It is an essential component for numerous oxidation reduction enzymes (cytochrome oxidase, uricase and tyrosinase). The toxicity of copper depends on the hardness and $\mathrm{pH}$ of water, it is more toxic in soft water with low alkalinity (Taha, 2004). Copper concentrations in muscles of $O$. niloticus collected from Rosetta Branch of River Nile were increased at stations II and III especially in winter Table (2). The observed decrease in $\mathrm{Cu}$ concentration in muscles of $O$. niloticus is mainly due to, the decrease in $\mathrm{Cu}$ concentration in water, where $90 \%$ of $\mathrm{Cu}$ in water was complexes by dissolved organic materials and suspended matters (El-Hadad, 2005). Our results in the present study are in agreement with that, recorded by Gad and Yacoub (2009) and Gad and Mohamed (2010).

Manganese $(\mathrm{Mn})$ is essential for aquatic organisms, its present below limited concentrations in their bodies due to its role in physiological metallo-enzymes, bone structure and for normal functioning of nervous system (WHO, 1996). In the present study the maximum Mn level was observed in muscles of $O$. niloticus collected from station III in winter. According to FAO (1992) and the Egyptian standards (1993), there is no information on the carcinogenicity of manganese. WHO (1994) recommended that, manganese intake from food, water and dietary supplement should not exceeded the tolerable daily upper limit of $11 \mathrm{mg} / \mathrm{day}$.

Cadmium $(\mathrm{Cd})$ is a non-essential element which has several toxic effects on fish. Cd can damage gills and disturbed calcium balance, $\mathrm{Cd}$ may replace $\mathrm{Zn}$ in certain enzymes, causing disease, severely limited oxygen metabolism of mitochondria in the liver of fish and know to accumulate in gills, liver and kidney of fish (Wicklund et al., 1992) .

The concentration of cadmium in muscles of $O$. niloticus collected from the three sampling stations were higher at station III Table (2), this may duo to the impact of sewage and the industrial wastes. Cd concentrations in O. niloticus muscles were below the maximum permissible level. In the other hand $\mathrm{Cd}$ was not detected in muscles of $O$. niloticus collected from Rosetta Branch of River Nile at station I (relatively unpolluted site). Results of the present study revealed that, fish samples 
collected from different sites of Rosetta Branch of River Nile displayed significant amount of heavy metals $(\mathrm{Fe}, \mathrm{Zn}, \mathrm{Mn}, \mathrm{Cu}$ and $\mathrm{Cd}$ ) in their muscles, where minimum values were recorded in summer and maximum values were in winter, these observations maybe attributed to seasonal variation in water temperature, with subsequent influence of detoxification rate and accumulation of toxicant (Haggag $\boldsymbol{e t}$ al., 1999).

The accumulation patterns of trace metals found in muscles of $O$. niloticus collected from Rosetta Branch of River Nile in the following order: $\mathrm{Fe}>\mathrm{Zn}>\mathrm{Mn}>$ $\mathrm{Cu}$ and $\mathrm{Cd}$. The concentrations of heavy metals ( $\mathrm{Zn}, \mathrm{Mn}, \mathrm{Cu}$ and $\mathrm{Cd}$ ) in muscles of $O$. niloticus from stations II and III in the present study were within the permissible limits except $(\mathrm{Fe})$. Consequently there was a public health risk from fish consumption especially that caught from Kafr El-Zayat station III, which contaminated by industrial effluents of El-Malyia Company which poured directly into the branch without treatments (Yehia and Sebaee, 2012).

\section{Antioxidant defence system}

in the present study the activates of antioxidant enzymes (SOD, CAT, GPX, GST and GR) and oxidative stress biomarker (MDA) in liver and white muscles of $O$. niloticus collected from Rosetta Branch of River Nile, were increased significantly (P $\leq 0.05)$ at stations II and III, these sites are polluted by sewage and industrial effluents, Table (1). The observed increase in antioxidant enzymes activities indicates adaptive responses of fish to counteract the oxidative effect of generated ROS or due to resist the water pollutants toxicity against the damage caused by excessive amount of oxygen free radicals and oxidative stress (Gad, 2009 and Carvalho et al., 2012). On seasonal bases the concentrations of antioxidant enzymes (SOD, CAT, GPX, GST and GR) as well as oxidative stress biomarker (MDA) levels in the present study, were increased in cold season (winter) compared to hot season (summer). This indicates that, low temperature induce more free radical, which led to oxidative stress damage in tissues and more antioxidant enzymes were produced to reduces the damaging effect of free radicals.

This response may be due to one or more of the following two reasons: (i) temperature decrease weakens the systems of ROS elimination (Lushchak, 2011). (ii) Fish at low temperatures also implies an increase in unsaturated fatty-acid in membrane lipids as a strategy to maintain membrane function as well as a higher risk of lipid hydrogen peroxide formation and oxidative injury (Guderley and StPierre, 2002). The critical effects of cold seasons (low temperature) are changes in the properties of cellular membranes, such as decreases in membrane fluidity. Compensatory responses to these effects of low temperature include changes in membrane phospholipid composition, causing changes in a variety of membrane properties such as membrane fluidity, membrane phase behavior, membrane thickness, and membrane permeability (Crockett, 1998). Another common response to cold seasons is an increase in mitochondrial enzyme amounts, which is often associated with an increase in the density of mitochondria in a tissue (O'Brien, 2011).

End-product of oxidative stress (MDA) may also increase at cold seasons simply because; oxygen is more suitable in aqueous fluids at low temperatures, increasing the oxygen concentration of cytoplasm. Although cold exposure has been associated with decreases in tissue oxygenation as a result of reduced cardiac performance (Pörtner, 2010). Consistent with this second hypothesis, cold seasons are associated with increases in the expression of the hypoxia inducible factors (HIF) and increases in the DNA-binding activity of this transcription factor, which ultimately result in increases in tissue capillarity that are thought to help restore 
oxygen delivery as well as increases in the amount of myoglobin in critical tissues such as the heart (Heise et al., 2007).

The observed increase in antioxidant defence enzymes and oxidative stress biomarker in fish tissues (white muscles and liver) were in agreement with the recorded in gold fish and C.carpio (Lushck et al., 2005) and in P. mesopotamicus exposed to $\mathrm{Cu}$ and hypoxia (Garcia-sampaio, 2008).

In the present study the concentration of heavy metals $\mathrm{Fe}, \mathrm{Zn}, \mathrm{Cu}, \mathrm{Mn}$ and $\mathrm{Cd}$ in water samples and their accumulation levels in fish muscles were higher at Kafr ElZayat industrial area Tables (1 and 2), which causes alternations in the antioxidant defence enzymes and oxidative stress biomarker. Consequently the activities of SOD, CAT and GST were elevated in all O. niloticus white muscles and liver at polluted sites. The significant increase in these organs may be a response to oxidative stress caused by the presence of heavy metals in water samples at stations II and III.

The significant increase in (GPx and GST) activity in white muscles and liver of sampled O. niloticus at polluted stations II and III, suggests a protective and adaptive role against oxidative stress induced by the heavy metals present in water samples of the same sites. Our results are in agreement with the findings of Farombi et al. (2007). While, fish trying to adapt to pollutants and oxidative conditions relatively higher (GR) activity was observed in present work in white muscles and liver of $O$. niloticus collected from polluted stations II and III. Stephensen et al. (2000) demonstrated that fishes from polluted sites have high GR activity due to higher peroxidative components in the polluted aquatic site.

Our results indicate a significant elevation of lipid peroxidation end-product (MDA) in O. niloticus white muscles and liver. The apparent increase in MDA may be attributed to the accumulation of the heavy metals, as our data indicate significant concentration of heavy metals accumulation in muscles of sampling fish from polluted stations II and III. Same results were recorded in C. gariepinus collected from heavily polluted River nearby major industries in Nigeria (Farombi et al., 2007), in Oreochromis niloticus, Tilapia rendalli, and Geophagus brasiliensis collected from metal contaminated site (Ruas et al., 2008), in Catostomus commersoni collected from Québec River (Canada), which impacted by agricultural chemicals (Dorval et al., 2005), also in (Cyprinus carpio fish from rural and industrial sites in Western Ukraine (Falfushynska and Stoliar, 2009).

In present study all antioxidant enzymes and MDA level recorded in liver were higher than white muscles, especially in cold seasons. This may be referring to the strong constitutive antioxidant potential in liver, to resist ROS generation. Liver is a very active tissue metabolically, white muscle has a limited set of physiological functions and anaerobic metabolism dominates during burst swimming activity. Because of this, it appears that muscle is equipped with much lower activities of the main antioxidant enzymes (Kubrak et al., 2012). Moreover, the several potential sources of ROS in liver, as liver contains high levels of cytochromes P450, which are involved in fatty acid metabolism and detoxify xenobiotics, generating ROS as a byproduct of these reactions, this high levels of cytochromes, liver contains more iron than muscle (Canli and Atli, 2003), and free iron reacts with hydrogen peroxide via the Fenton reaction, producing hydroxyl radicals, the most damaging form of ROS (McCord, 1998). 


\section{CONCLUSION}

In conclusion, this study revealed that enzymatic responses of $O$. niloticus to heavy metal exposures lead to a significant increase in activity of antioxidant defense system enzymes (SOD, CAT, GPx, GST and GR) and lipid peroxidation indicator MDA in white muscles and liver of O. niloticus from polluted Rosetta Branch of River Nile. Levels of heavy metals in the present study elevated at station II (Al-Qata) because of the extended negative effect of El-Rahawy drain; station III (Kafr ElZayat) recorded the highest concentration of metals, because of the industrial effluents. This enzymatic response can serve as biomarkers for early detection of pollution during biomonitoring programs. There is a need for extensive evaluation and comparison of data obtained from field studies and those obtained from laboratory studies.

From economical prospect, fish health management is a critical aspect of fish farming and production, especially during the last five years, farmers have been confronted with disease outbreaks, which have occasionally led to the death of all fish in ponds, and hence considerable economic losses. Diseases also affect the quantity, quality and prices of fish in the market. Moreover, low water quality is due to the presence of agriculture, industrial, municipal wastewater and discharges from drains along the course of Nile River. So, more attention should be paid to pollutants discharge into the River Nile without any treatment especially heavy metals. As known, free radical involved in pathogenesis of many immune disease and organs malfunction, so adding some dietary antioxidant (beta-carotene, vitamin A, vitamin $\mathrm{E}$ and vitamin $\mathrm{C}$ ) to fish diet could help in disease resistance, improve fish health and mortality control.

\section{REFRENCES}

Abdel-Dayem, S.; Abdel-Gawad, S; and Fahmy, H. (2007). Drainage in Egypt: A story of determination, continuity, and success. Irrig. Drain 56: S101-S111.

Abdel-Moati, M. A. R. and El-Sammak, A. A. (1997). Man-made impact on the geochemistry of the Nile delta lakes: a study of metals concentrations in sediments. Water Air and Soil Contamination 97: 413-429.

Adeyeye, E. I.; Akinyugha, N. J.; Fesobi, M. E. and Tenabe, V. O. (1996). Determination of some metals in Clarias gariepinus (Cuvier and Vallenciennes), Cyprinus carpio (L.) and Oreochromis niloticus (L.) fishes in a polyculture fresh water pond and their environments. Aquaculture, 147(3-4): 205-214.

Ahmed, M. K; Shaheen, N.; Islam, M. S.; Al-Mamun, M. H.; Islam, S.; Mohiduzzaman, M. and Bhattacharjee, L. (2015). Dietary intake of trace elements from highly consumed cultured fish (Labeorohita, Pangasius pangasius and Oreochromis mossambicus) and human health risk implications in Bangladesh. Chemosphere, 128: 284-292.

APHA (American Public Health Association) (2012). Standard Methods for examination of water and wastewater (22nd ed.)American Public Health Association, American Water Works Association (AWWA) and Water Environment Federation (WEF), Washington.

Authman, M. M. and Abbas, H. H. (2007). Accumulation and distribution of copper and zinc in both water and some vital tissues of two fish species (Tilapia zillii 
and Mugil cephalus) of Lake Qarun, Fayoum Province, Egypt. Pakistan J Biol. Sci. 10(13): 2106-2122.

Authman, M. M. N.; Ibrahim, S. A.; El-Kasheif M. A. and Gaber, H. S. (2013). Effect of Water Pollution in El-Rahawy Drainage Canal on Hematology and Organs of Freshwater Fish Clarias gariepinus. J. World Appli. Sci., 21(3): 329341.

Barbosa-Morais, N. L.; Irimia, M.; Pan, Q.; Xiong, H. Y.; Gueroussov, S.; Lee, L. J. and Kim, T. (2012). The evolutionary landscape of alternative splicing in vertebrate species. Science, 338(6114): 1587-1593.

Buege, J. A. and Aust, S. D. (1978). Microsomal lipid peroxidation. Methods Enzymol. 52: 302-310.

Canli, M. and Atli, G. (2003). The relationships between heavy metal $(\mathrm{Cd}, \mathrm{Cr}, \mathrm{Cu}$, $\mathrm{Fe}, \mathrm{Pb}, \mathrm{Zn}$ ) levels and the size of six Mediterranean fish species. Environ. Pollut. 121:129-136.

Carvalho, C. S.; Bernusso, V. A.; De Araújo, H. S.; Gaeta Espí ndola, E. L. and Fernandes, M. N. (2012). Biomarker responses as indication of c ontaminant effects in Oreochromis niloticus. Chemos phere, 89(1): 60-69.

Crockett, E. L. (1998). Cholesterol function in plasma membranes from ectotherrns: membrane specific roles in adaptation to temperature. American Zoologist 38(2): 291-304.

Dorval, J.; Leblond, V.; Deblois, C. and Hontela, A. (2005). Oxidative Stress and Endocrine Endpoints in White Sucker (Catostomus commersoni) from a River Impacted by Agricultural Chemicals. Environ. Toxicol. and Chem., 24(5): 12731280.

Egyptian Governmental Law No. 48/ 1982- Decision 92 (2013). The implementer regulations for Law 48/ 1982, 92/ 2013 regarding the protection of the River Nile and water ways from pollution. Map Periodical Bull: 21-30.

Egyptian, Organization for Standardization and Quality control (1993). Maximum Level for Heavy Metal Contamination in Food. ES No. 2360.

El Bouraie, M. M.; El Barbary, A. A.; Yehia, M. M. and Motawea, E. A. (2010). Heavy metal concentrations in surface river water and bed sediments at Nile Delta in Egypt. Suo-Mires and peat, 61: 1-12.

Elghobashy, H.; Khalid, A.; Zaghloul, H.; Mahmoud, A. and Metwally A. (2001). effect of some water pollutants on the Nile Tilapia, Oreochromis niloticus collected from the River Nile and some Egyptian lakes Egypt. J. AquaL BioL A Fish., 5(4): $251-219$.

El-Haddad, E. S. M. (2005). Some environmental studies on water and sediment of Ismailia Canal from El-Mazallat to Anshas Region (M. Sci. Thesis). Fac. of Sci., Al-Azhar Univ. Egypt, : 218.

El-sayed, M. and Ouf, E. A. (2009). studies on River Nile aquatic environment II organic pollutants. Am-Euras J. Agric. And Environ. Sci., 5: 159 - 170.

Falfushynska, H. and Stolyar, O. (2009). Responses of Biochemical Markers in Carp Cyprinus carpio from Two Field Sites in Western Ukraine, Ecotoxicol. and Environ. Safe. 72: 729-36.

FAO (Food and Agricultural Organization) (1983). Compilation of legal limits for hazardous substances in fish and fishery products. Fisheries circular No. 764. FAO, Rome. Italy: 102.

FAO (Food and Agricultural Organization) (1992). Committee for inland fisheries of Africa; Report of the third session of the working party on pollution and fisheries. Accra, Ghana. 25-29 November 1991. FAO fisheries. Rep., No. 471. Rome, FAO: 43. 
Farombi, E. O.; Adelowo, O. A. and Ajimoko, Y. R. (2007). Biomarkers of oxidative stress and heavy metal levels as indicators of environmental pollution in African Cat fish (Clarias gariepinus) from Nigeria Ogun River. Int. J. Environ. Res. Public Health, 4(2):158-165.

Gad, N. S. (2009). Determination of glutathione related enzymes and cholinesterase activities in Oreochromis niloticus And Clarias gariepinus as bioindicator for pollution in Lake Manzala. Global Vet., 3(1): 37-44.

Gad, N.S. and Ibrahim, S. A. (2005). Assessment of some heavy metals in tissues of Nile cat fish $C$. gariepinus from aquatic canal and their effects on some biochemical and haematological parameters. J. Egypt Ger. Soci. Zool., 48 (A): 45-64.

Gad, N. S. and Yacoub, A. M. (2009). Antioxidant defense agents and physiological responses of fish to pollution of Rosetta Branch of the River Nile, Egypt. Egypt. J. Aquat. Biol. Fish., 13(4): 109- 128.

Gad, N. S. and Mohamed, A. F. (2010). Distribution and accumulation of some trace metals in water and fish from Damietta branch of River Nile. African, J. BiolSci., 6(1): 95-115.

Garcia Sampaio, F. G.; Boijink, C. L.; Oba, E.T.; Santos, L. R. B.; Kalinin, A. L. and Rantin, F. (2008). Antioxidant defenses and biochemical changes in pacu (Piaractus meso potamicus) in response to single and combined copper and hypoxia exposure. Comp. Biochem. Physiol. 147 (C): 43-51.

Genestra, M. (2007). Oxyl radicals, redox-sensitive signaling cascades and antioxidants. Review. Cell Signal., 19: 1807-1819.

Ghazaly, K. S. (1988). The bioaccumulation of heavy metals in the tissues of the Egyptian edible marine animals. Part I. Crustaceans. Bulletin of National Institute of Oceanography and Fisheries, A.R.E., 14: 71-77.

Guderley, H. and St-Pierre, J. (2002). Going with the flow or life in the fast lane: contrasting mitochondrial responses to thermal change. J. Exp. Biol., 205: 2237-2249.

Habig, W. H.; Pabst, M. J. and Jakoby, W. B. (1974). Glutathione-S-transferase. The first enzymatic step in mercapturic acid formation. J. Biol. Chem., 249(22): 7130-7139.

Haggag, A. M.; Mohamed, A.; Marie, S. and Khalid, H. Z. (1999). Seasonal effects of the industrial effluents on the Nile catfish Clarias gariepinus. J.Egypt. Ger.Soc.Zool., 28(A): 365-391.

Hegazi, M. M.; Attia, Z. I. and Ashour, O. A. (2010). Oxidative stress and antioxidant enzymes in liver and white muscle of Nile tilapia juveniles in chronic ammonia exposure. Aquat. Toxicol., 99(2): 118-125.

Heise, K.; Estevez, M. S.; Puntarulo, S.; Galleano, M.; Nikinmaa, M.; Portner, H. O. and Abele, D. (2007). Effects of seasonal and latitudinal cold on oxidative stress parameters and activation of hypoxia inducible factor (HIF-1) in zoarcid fish. J. Comp. Physiol., 177(B): 765-777.

Ikem, A. and Egiebor, N. O. (2005). Assessment of trace elements in canned fishes (mackerel, tuna, salmon, sardines and herrings) marketed in Georgia and Alabama (United States of America). Journal of Food Composition and Analysis, 18: 771-787.

Islam, M. S; Ahmed, M. K.; Raknuzzaman, M.; Habibullah-Al-Mamun, M. and Masunaga S. (2015a). Metal speciation in sediment and their bioaccumulation in fish species of three urban rivers in Bangladesh Arch. Environ. Contam. Toxicol., 68: 92-106. 
Islam, M. S.; Ahmed, M. K.; Raknuzzaman, M.; Habibullah-Al-Mamun, M. and Masunaga, S. (2015 b). Assessment of trace metals in fish species of urban rivers in Bangladesh and health implications. Environ. Toxicol. Pharmacol., 39: 347-357.

Kadar, E.; Bettencourt, R.; Costa, V.; Santos, R. S.; Lobo-Da-Cunha, A. and Dando, P. (2005). Experimentally induced endosymbiont loss and reacquirement in the hydrothermal vent bivalve Bathymodiolus azoricus. J Exp Mar Biol Ecol., 318: 99-110.

Kubrak, O. I.; Rovenko, B. M.; Husak, V. V.; Storey, J. M.; Storey, K. B. and Lushchak, V. I. (2012). Nickel induces hyperglycemia and glycogenolysis and affects the antioxidant system in liver and white muscle of goldfish Carassius auratus L. Ecotoxicol. environ. Safe., 80: 231-237.

Lee, K., Kweon, H., Yeo, J., Woo, S., Han, S. and Kim, J. H. (2011). Characterization Of tyrosine-rich Antheraea Pernyi silk fibroin hydrolysate. Int. J. Biol. Macromol., 48, 223-226.

Lushchak, V. I. (2011). Environmentally induced oxidative stress in aquatic animals. Aquat. Toxicol., 101:13-30.

Lushchak, V. I.; Bagnyukova, T. V.; Lushchak, O. V.; Storey, J. M. and Storey, K. B. (2005). Hypoxia and recovery perturb free radical processes and antioxidant potential in common carp (Cyprinus carpio) tissues. Int. J. Biochem. Cell. Biol. 37:1319-1330.

Malik, N.; Biswas, A.; Qureshi, T.; Borana, K. and Virha, R. (2010). Bioaccumulation of heavy metals in fish tissues of a freshwater Lake of Bhopal .Environ.Monit. Assesss., 160(1-4): 267-276.

McCarthy, T. F. and Shugart, I. R. (1996). Biomarkers of environmental contamination. Lewis Publishers, New York: 425.

McCord, J. M. (1998). Iron, free radicals, and oxidative injury. Semin. Hematol. 35: 5- 12.

Melegaria, S. P.; Perreaulut, F.; Costa, R. H.; Popovic, R. and Matiasa, W. G. (2013). Evaluation of toxicity and oxidative stress induced by copper oxide nanoparticles in the green alga; Chlamydomonas reinhardtii .Aquat. Toxicol., 142: 431-440.

NAWQAM (2003). Nile Research Institute data. National Water Quality and Availability Management Project (NAWQAM), National Water Research Centre. Egypt.

O'Brien, K. M. (2011). Mitochondrial biogenesis in cold-bodied fishes. J. Exp. Biol. 214: $275-285$.

Paglia, D. E. and Valentine, W. N. (1967). Studies on the quantitative and qualitative characterization of erythrocyte glutathione peroxidase. J. Lab. Clin. Med., 70(1): 158-169.

Paoletti, F. and Mocali, A. (1990). Determination of superoxide dismutase activity by purely chemical system based on NADPH oxidation, Methods Enzymol. 186: 209-220.

Pereira, C. D. S.; Martins-Dias, M. L.; Zanette, J.; Cesar, A.; Choueri, R. J.; Abessa, D. M. S.; Catharino, M. G. M.; Vasconcellos, M. B. A.; Bainy, A. C. D.; Sousa, E. C. P. and DelValls, T. A. (2011). Integrated biomarker responses as environmental status descriptors of a coastal zone (Sao Paulo, Brazil). Ecotoxicology and environmental safety, 74(5): 1257-1264.

Pörtner, H. O. (2010). Oxygen- and capacity-limitation of thermal tolerance: a matrix for integrating climate-related stressor effects in marine ecosystems. J. Exp. Biol. 213: 881-893. 
Ruas, C. B. G.; dos Santos Carvalho, C.; de Araújo, H. S. S.; Espíndola, E. L. G. and Fernandes, M. N. (2008). Oxidative stress biomarkers of exposure in the blood of cichlid species from a metal-contaminated river. Ecotoxicol. and environ. Safe., 71(1): 86-93.

Smith, I. K.; Vierheller, T. L. and Thorne, C.A. (1988). Assay of glutathione reductase in crude $\mathrm{t}$ issue homogenates using 5,5'-dithiobis(2- nitrobenzoic acid). Anal. Biochem., 175(2): 408-413.

Spear, P. A. (1981). Zinc in the aquatic environment: chemistry, distribution, and toxicology Vol. 17589. Science Criteria Environmental Quality Publication. Natural Resources Council of the Canadian Association of Communities.

Stara, A.; Machova, J. and Velisek, J. (2012). Effect of chronic exposure to simazine on oxidative stress and antioxidant response in common carp (Cyprinus carpio L.). Environ. Toxicol. And pharmacol., 33(2): 334-343.

Stephensen, E.; Svavarsson, J.; Sturve, J.; Ericson, G.; Adolfsson-Erici, M. and Forlin, L. (2000). Biochemical Indicators of Pollution Exposure in Shorthorn Sculpin (Myoxocephalus scorpius), Caught in Four Harbors on the Southwest Coast of Iceland. Aqua. Toxicol., 48: 431-442.

Taha, A. A. (2004). Pollution Sources and Related Environmental Impacts in the New Communities, Southeast Nile Delta, Egypt. Emirat. J. Eng. Res. 19(1): 44.

WHO (1994). Quality directive of potable water (2nd ed., p. 197). Geneva: World Health Organization.

WHO (1996). Guidelines for Drinking Water Quality, 2nd edition, World Health Organization, Geneva.

Wicklund Glynn, A.; Haux, C. and Hogstrand, C. (1992). Chronic toxicity and metabolism of $\mathrm{Cd}$ and $\mathrm{Zn}$ in juvenile minnows (Phoxinus phoxinus ) exposed to a Cd and Zn mixture. Can. J. Fish. Aquat. Sci., 49: 2070-2079.

Xu, J. B.; Yuan, X. F. and Lang, P. Z. (1997). Determination of catalase activity and catalase inhibition by ultraviolet spectrophotometry. Chin. Environ. Chem., 16: 73-76.

Yehia H. M. and Sebaee E. Sh. (2012). Bioaccumulation of heavy metals in water, sediment and fish (Oreochromis niloticus and Clarias anguillaris), in Rosetta branch of the River Nile, Egypt. African J. of Biotec., 11(77): 14204-14216.

Zyadah, M. A. (1995). Environmental impact assessment of pollution in Lake Manzalah and its effect on fishes. Ph.D. Thesis, Faculty of Science, ElMansoura University, Egypt: 127.

\section{ARABIC SUMMARY}

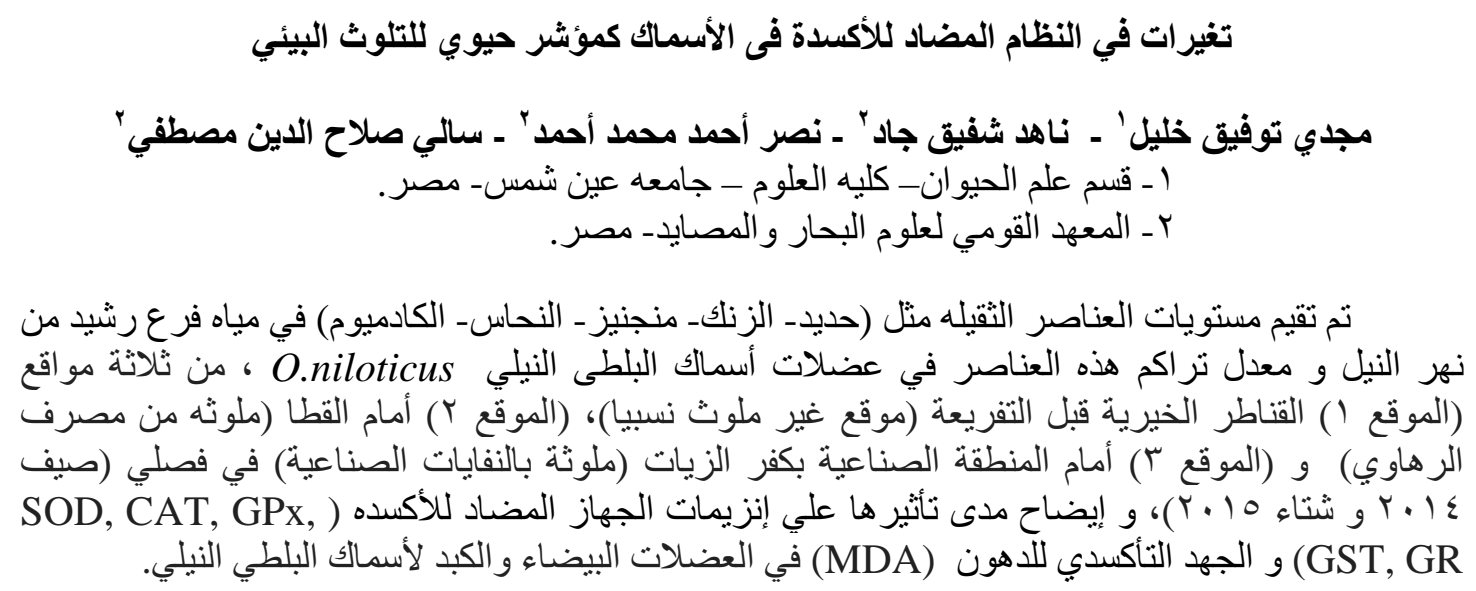




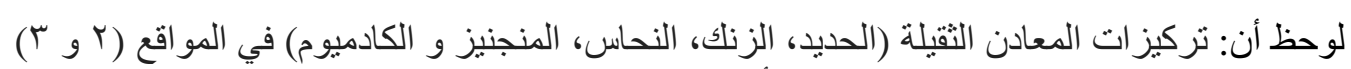

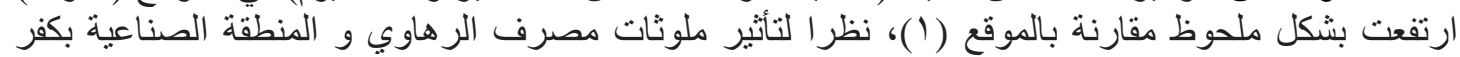

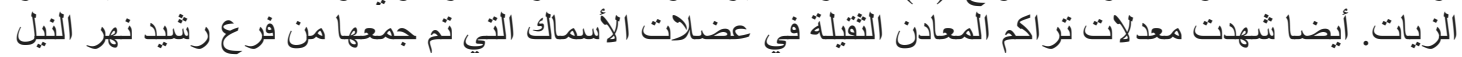

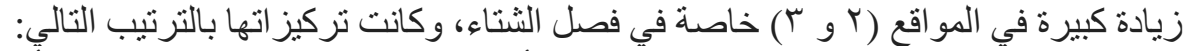

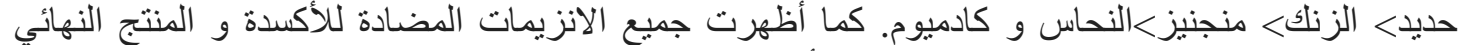

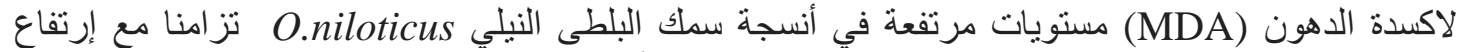

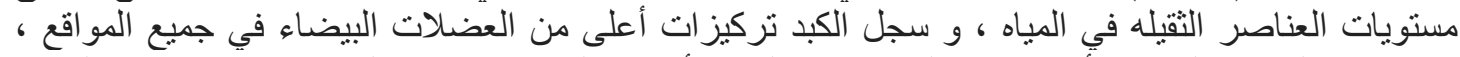

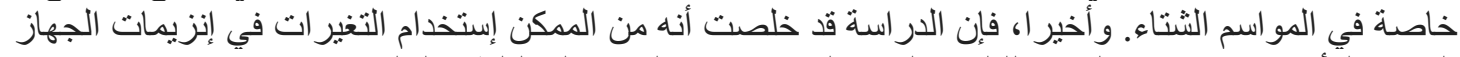
المضاد للأكسده كمؤشر بيولوجي للتلوث البيئي الذي تنتعرض له اسماك البلطي النيلي O.niloticus. 